\title{
Effect of Genotypes on Chemical and Physical Properties of Mulberry
}

\section{Dutların Fiziksel ve Kimyasal Özellikleri Üzerine Genetopin Etkisi}

\author{
Research Article
}

\section{Fatma Hepsağ'*, Özgür Gölge', ibrahim Hayoğlu²}

'Ministry of Food, Agriculture and Livestock, General Directorate of Food and Control, Food Control Laboratory, Adana, Turkey. ${ }^{2}$ Harran University, Faculty of Agriculture, Department of Food Engineering, Şanlıurfa, Turkey.

\section{A B S TR AC T}

$\mathrm{n}$ this research, the physico-chemical properties and mineral composition of white (Morus alba L.), black (M. nigra L.) and urmu (M. nigra L.) mulberries, grown in Southeast Anatolia region of Turkey, were investigated. Urmu contained the highest total anthocyanin and phenolic compounds (1071 mg cyanidin-3-glucoside equivalents, and $1456 \mathrm{mg}$ gallic acid equivalents/100 g fresh matter respectively), and white mulbery had the highest HMF and browning index ( $36.15 \mathrm{mg} \mathrm{kg}^{-1}$ and 17.61 respectively). Maximum $L$ and $b$ values were observed in white mulberry. The mean values of mineral compositions of the mulberry types in $100 \mathrm{~g}$ fresh fruith were $238 \mathrm{mg}$ P, $1138 \mathrm{mg} \mathrm{K}, 139 \mathrm{mg} \mathrm{Ca}, 116 \mathrm{mg} \mathrm{Mg}, 6 \mathrm{mg} \mathrm{Fe}, 0.8 \mathrm{mg} \mathrm{Cu}, 4.3 \mathrm{mg} \mathrm{Mn}$ and $3.9 \mathrm{mg} \mathrm{Zn}$. The highest total flavonoid and ascorbic acid were determined in urmu mulberry (312 $\mathrm{mg}$ quercetin equivalents/100 g fresh matter and 32 $\mathrm{mg} / 100 \mathrm{~g})$.

\section{Key Words}

Anthocyanins, HMF, minerals, phenolics.

\section{ÖZET}

u çalışmada, Türkiye'nin Güneydoğu Anadolu bölgesinde yetiştirilen beyaz (Morus alba L.), siyah (M. nigra L.) ve urmulu (M. nigra L.) dutların fiziko-kimyasal özellikleri ve mineral bileşimi araştırılmıştır. Urmulu dutlar en yüksek toplam antosiyanin ve fenolik bileşikler içerirken (1071 mg siyanidin-3-glikozit eşdeğerleri, ve 1456 mg gallik asit /100 g taze madde sırasıyla eşdeğer) ve beyaz dut en yüksek HMF ve esmerleşme indeksine (36.15 mg kg-1 ve 17.61 sırasıyla) sahiptir. Maksimum L ve b değerleri beyaz dutlarda gözlenmiştir. 100 gram taze dut meyvesi çeşitlerinin mineral bileşimlerinin ortalama değerleri 238 mg P, 1138 mg K, 139 mg Ca, Mg 116 mg, $6 \mathrm{mg} \mathrm{Fe}, 0.8 \mathrm{mg} \mathrm{Cu}, 4.3 \mathrm{mg} \mathrm{Mn}$ ve $3.9 \mathrm{mg} \mathrm{Zn}$. En yüksek toplam flavonoid ve askorbik asit (312 mg kuarsetin/100 $\mathrm{g}$ taze madde ve $32 \mathrm{mg}$ eşdeğer/100 g) urmulu dutta belirlenmiştir.

\section{Anahtar Kelimeler}

Antosiyaninler, HMF, mineraller, fenolikler.

Article History: Received: Feb 12, 2016; Revised: May 17, 2016; Accepted: Jun 20, 2016; Available Online: Jul 31, 2016.

DOI: 10.15671/HJBC.20164420565

Correspondence to: F. Hepsağ, Ministry of Food, Agriculture and Livestock, General Directorate of Food and Control, Food Control Laboratory, Adana, Turkey. 


\section{INTRODUCTION}

Trad raditionally, deep coloured fruits and vegetables are considered as healthier for human body, especially in oriental countries. The mulberry belongs to the genus Morus of the family Moraceae. There are 24 species of Morus and one subspecies, with at least 100 known varieties. Mulberry (Morus sp.) has deep coloured fruits. Due to its high adaptability, mulbery is grown in the diverse climatic and soil conditions, especially in chalky and clay soils, and is resistant to drought to some extent.

Around 2.5 million mulbery trees are naturally grown in different regions of Turkey, and annually 75 thousand tons of mulbery fruit is harvested between June and August. The main mulberry production area in Turkey is Black Sea region followed by eastern and central regions.

There are, economically important, three types of mulberry that grown in Turkey: 95\% Morus alba L. (white), 3\% M. nigra L. (black) and $2 \%$ M. rubra L. (red). M. nigra has two types of fruit, one is black the other is reddish-black known as urmu [1-5] The mulbery fruits are consumed either as fresh or processed in diverse products. Fresh mulberries are very perishable; its transportation and marketing is very difficult, and can only be stored for maximum of six weeks in cold conditions. For longer storage, further processing is required [5]. Mulberry fruit can be processed into jams, marmalades, juices, syrups, natural dyes for cosmetic and medicine industry in Turkey [1]. Though there are many studies on various mulberry types in general, limited comparative study is available concerning the physico-chemical and mineral composition of white, black and urmu mulbery types that grown in the same ecological conditions. The objective of this research is to determine and compare some physico-chemical characteristics and mineral compositions of these mulbery types.

\section{MATERIALS and METHODS}

\section{Materials}

The samples from white, red and black mulberry types were harvested by hand in Adıyaman province, Southeast Anatolia, Turkey, between $5^{\text {th }}$ and $20^{\text {th }}$ of July. The samples were kept at $-20^{\circ} \mathrm{C}$ for further studies.

\section{Chemicals and Reagents}

Folin-Ciocalteu reagent, 2,2-diphenyl-1picryl hydrazyl (DPPH), 5-(hydroxymethyl)2-furaldehyde, barbituric acid, p-toluidine, potassium metabisulfite, sodium hydroxide, potassium chloride, sodium acetate, ascorbic acid, meta-phosphoric acid, oxalic acid, catechin, sodium nitrate, aluminum chloride, n-hexane, nitric acid and hydrogen peroxide were supplied from Sigma-Aldrich (St. Louis, MO, USA). Distilled water, for the HPLC mobile phase and all analytical steps were produced in an Elix 5 water purification system (Millipore, Molsheim, France).

\section{Apparatus}

Fruit colours were measured using a CR-400 chromometer (Konica Minolta, Japan). UV-VIS lambda 25 spectrophotometer was used to determine ascorbic acid, HMF, total anthocyanins, total phenolics, total flavonoids and browning index (Perkin Elmer, Waltham, MA, USA). ICP OES Optima 2100 was used to determine mineral element content (Perkin Elmer, Waltham, MA, USA).

\section{Methods \\ Preparation of the Mulberries Extract}

$5 \mathrm{gr}$ fresh fruit was homogenised in $100 \mathrm{ml}$ ethanol-water $(1: 1, v / v)$ in a blender. The mixture was subjected to an ultrasonic bath for 60 min. The suspension was filtered through Whatman No. 1 filter paper (Sigma-Aldrich, St. Louis, Missouri, USA). The extracts were stored in a refrigerator till the analyses were carried out.

\section{Physicochemical Properties}

The samples were analysed for fruit weight, fruit colour, $\mathrm{pH}$, total soluble solid content as outlined by [6]. The $\mathrm{pH}$ was measured using digital pH-meter (WTW Inolab, Weilheim, Germany). Titratable acidity was determined potentiometrically titrating the samples with $0.1 \mathrm{~N}$ $\mathrm{NaOH}$, and expressed as percent citric acid. Total dry matter was determined gravimetrically. Total soluble solid content (TSS) was measured using Abbe refractometer (250 HE, Kyoto, Japan) at $20^{\circ} \mathrm{C}$. 


\section{Measurements of the Mulberyfruit's Color}

Fruit colour was measured using a CR-400 chromometer (Konica Minolta, Japan), and result were recorded as $L$ (lightness), +a (redness) and $+b$ (yellowness). The colorimeter was calibrated with white reference layer (Number: 14533046) before measurement [7].

\section{Determination of the Total Anthocyanin Content}

Total anthocyanin content was determined by the $\mathrm{pH}$ differential method. Briefly, $\mathrm{pH} 1.0$ buffer was prepared by using $0.2 \mathrm{M} \mathrm{KCl}$ and $0.2 \mathrm{~N} \mathrm{HCl}$ solutions. Buffer at $\mathrm{pH} 4.5$ was prepared by using sodium acetate and $\mathrm{pH}$ was adjusted with acetic acid. Absorbance was measured at 520 and 700 nm using UV-VIS spectrophotometer.

Data were expressed as $\mathrm{mg} / 100 \mathrm{~g}$ cyaniding3-glucoside fresh matter. The absorbance of each sample was calculated using the following equation $[6,8]$ :

$A=\left(A_{510} \mathrm{pH} 1.0-A_{700} \mathrm{pH} 1.0\right)-\left(A_{510} \mathrm{pH} 4.5-\mathrm{A}_{700}\right.$ $\mathrm{pH}$ 4.5)

\section{Determination of HMF}

10 grams of fruit was dissolved in $20 \mathrm{ml}$ water, and transferred to a 50 volumetric flask. $2 \mathrm{ml}$ of the solution and $5.0 \mathrm{ml}$ of $\mathrm{p}$-toluidine solution were transferred into two test tubes; to the first tube $1 \mathrm{ml}$ of distilled water was added (reference solution); to the second $1 \mathrm{ml}$ of barbituric acid solution $0.5 \%$ (sample solution). The absorbance of the solutions at $285 \mathrm{~nm}$ was determined using a Perkin Elmer UV-visible spectrophotometer [9].

\section{Determination of Total Flavonoid}

Total flavonoid content was determined using a spectrophotometric method based on formation of flavonoid complex with aluminum. $3 \mathrm{~mL}$ deionized water and $0.3 \mathrm{~mL} \mathrm{NaNO}$, were added to both extract $(1 \mathrm{~mL})$ and standard catechin solution (50-500 mg $\left.\mathrm{L}^{-1}\right)$. After keeping $5 \mathrm{~min}$ at room temperature, $3 \mathrm{~mL}$ of $2 \% \mathrm{AlCl}_{3}$ solution was added; waited for $5 \mathrm{~min}$ and then $2 \mathrm{~mL}$ of $1 \mathrm{M} \mathrm{NaOH}$ was added. The solution was then made up with deionized water to $10 \mathrm{~mL}$. The absorbance was measured at $510 \mathrm{~nm}$. Total flavonoid content was calculated as milligrams of catechin equivalent (CE) per kilogram of fresh fruit using standart curve [10].

\section{Determination of Browning Index}

To obtain clarify the samples, ethyl alcohol was added, and then filtered and centrifuged. Potasium metabisulfide was added to the resulting samples and absorbance was determined at $420 \mathrm{~nm}$ [6].

\section{Determination of Total Phenolic}

Total phenolic compounds were measured using Folin-Ciocalteu and expressed as mg gallic acid per liter [11].

\section{Determination of Total Fat Content}

Approximately $5 \mathrm{~g}$ (a) fine grinded and homogenized samples were weighed on filter paper $(1 \mathrm{~mm})$ and put in soxhalet capsules. Clean and dry fat beakers were weighed (b). Soxhalet capsules were placed into soxhalet instrument. $2 / 3$ of soxhalet beakers were filled with hexane or petrolium ether. Soxhalet beakers were placed into the soxhalet. Suitable program for the choosen solvent was selected for extraction. After extraction, soxhalet beakers were placed into oven at $105^{\circ} \mathrm{C}$ for 1 hour. The dried soxhalet beakers were cooled and weighed (c) (TFC, 2004). The fat contents were calculated using equation below:

$\%$ Total fat content $=[(\mathrm{c}-\mathrm{b}) / \mathrm{a}] \times 100$

\section{Determination of Ascorbic Acid}

200-300 g sample (W) was weighed into a blender, and the same amount extraction solution (acetic acid solution $8 \%$ ) was added to sample. Samples and solutions were homogenized using blender for 2 minutes. $10-40 \mathrm{~g}$ of homogenized mixture was transferred to the $100 \mathrm{ml}$ rounded flask and filled upto $100 \mathrm{ml}$. with extraction solution. Flask was shaken vigorously, and then the solution was filtered. $5-20 \mathrm{~mL}$ of filtrate was placed into $50 \mathrm{~mL}$ erlenmayer flask. And the solution was titrated with 2,6 dichlorophenolindophenol (V) [12]. Amount of ascorbic acid was calculated as below;

Ascorbic acid $(\mathrm{mg} / 100 \mathrm{~g})=$ V.F.100/W

\section{Determination of Mineral Content}

Analysis for $\mathrm{P}, \mathrm{K}, \mathrm{Ca}, \mathrm{Mg}, \mathrm{Na}, \mathrm{Fe}, \mathrm{Cu}, \mathrm{Mn}$ and $\mathrm{Zn}$ were determined using ICP-OES Perkin Elmer Optima 2100. The samples were homogenized using blenders: $1 \mathrm{~g}$ of sample was transferred into 
the microwave oven vessels, on which $6 \mathrm{~mL} \mathrm{HNO}_{3}$ and $1 \mathrm{~mL}$ of $\mathrm{H}_{2} \mathrm{O}_{2}$ were added. After keeping for 10 15 minutes for pre-ashing, the vessels was placed in microwave oven, and digested upto $200^{\circ} \mathrm{C}$ under pressure for 1 hour. The digested samples were taken into sample tubes and diluted to 15 $\mathrm{mL}$ with ultra pure water. The sample tubes were placed into auto sampler of ICP-OES. Amount of each mineral was calculated using calibration curve of corresponding mineral. Conditions for the ICP-OES were: plasma $15 \mathrm{~L} / \mathrm{min}$, auxilary 0.2 17 min, nebulizer flow: $0.5517 \mathrm{~min}$, power of RF generator 1500 watt and sample flow rate $2 \mathrm{~mL} /$ $\min [13]$.

\section{Statistical Analysis}

The trial was arranged according to factorial design in completely randomised blocks. All the analyses were carried out triplicate. The data obtained were subjected to analysis of variance, the significant differences were tested using Duncan mutiple ranges test $(p<0.05)$ to determine the differences among treatments [14].

\section{RESULTS and DISCUSSION}

\section{Fruit Weight, Width, Length, Stalk, pH, Total} Soluble Solid Content, Total Dry Weight

The fruit weight, width and length, stalk and fruit colour, $\mathrm{pH}$, acidity, total soluble solid content (TSS) and total dry weight (TDW) of mulberry samples were given in Table 1. A total of 50 mulberry fruits were used to measure mean weight, stalk, width and length. The weight, width, length and stalk of mulberry types ranged between 3.85-4.08 gram, 16.82-17.87 mm, 25.62-29.82 $\mathrm{mm}$ and 3.76-4.01 $\mathrm{mm}$ respectively, with urmu mulberry having the biggest fruits. The $\mathrm{pH}$ ranged from 3.52 (urmu) to 5.40 (white), acidity from 0.14 (white), to 1.37 (urmu), TSS from 21.13 (white), to 25.13 (urmu), TDW from 62.22 (white) to 75.95 (urmu). The $L$ value ranged from +14.04 (black) to +77.04 (white), a value from +6.54 (black) to 11.04 (urmu), and $b$ value from 1.98 (black) to 15.01 (white).

According to the results, because of its higher TSS and TDW content, bigger and attractive colorful appearance, we can recommend urmu type mulberry for both processing fresh marketing. In a similar research, [1] determined fruit weight of mulberries between $2.14 \mathrm{~g}$ and $4.37 \mathrm{~g}$, with M. nigra having the biggest fruits. The moisture contents were from $71.5 \%(\mathrm{M}$. alba) to $74.6 \%$ (M. rubra), pH from 3.52 (M. nigra) to 5.60 (M. alba), acidity from $0.25 \%$ (M. alba) to $1.40 \%$ (M. nigra), TSS from $15.9 \%$ (M. rubra) to $20.4 \%$ (M. alba), and TDW from $24.41 \%$ (M. rubra) to $29.50 \%$ (M. alba). Fruit colour was determined as $L$ value, from +14.3 (M. nigra) to +78.4 (M. alba), a value from -13.6 (M. alba) to 8.55 (M. rubra), and b value from 1.72 (M. nigra) to 16.2 (M. alba).

\section{Total Phenolic, Total Anthocyanin, Total Flavonoid and Ascorbic Acid Content of Mulberries}

Total phenolic, total anthocyanin, total flavonoid and ascorbic acid content of mulberry types were given in Table 2. The content of total phenolic compounds and flavonoids depends on geographic location and soil on which the mulberry trees are grown, and plant genotype and cultivation conditions $[1,15]$. The content of total phenolic compounds were determined in urmu, black and white mulberries as 1456, 1006 and $401 \mathrm{mg} \mathrm{kg}^{-1}$ (expressed as GAE equivalent), respectively. [1], determined a similar content of total phenolics in the fresh black (1422 $\left.\mathrm{mg}^{\mathrm{kg}} \mathrm{g}^{-1}\right)$, red (1035 mg. $\left.\mathrm{kg}^{-1}\right)$ and white (181 mg. $\left.{ }^{-1}\right)$ mulberries. In the other studies; total phenolics in the fresh white and black mulberries were found 1175.3 and $1451.4 \mathrm{mg} \cdot \mathrm{kg}^{-1}$, respectively [5,15]. Total flavonoids (expressed as CE equivalent) in urmu, black and white mulberries were 312, 290 and 41 mg. $\mathrm{kg}^{-1}$, respectively. [15] determined $599.7 \mathrm{mg}$ $\mathrm{kg}^{-1}$ total flavanoids in the fresh white mulberries. [1] determined a similar content of total flavanoids in the fresh black $\left(276 \mathrm{mg} . \mathrm{kg}^{-1}\right)$, red $\left(219 \mathrm{mg} \cdot \mathrm{kg}^{-1}\right)$ and white (29 mg. $\left.\mathrm{kg}^{-1}\right)$ mulberries. [5] found total flavanoid content of black mulberries $768.7 \mathrm{mg}$ $\mathrm{kg}^{-1}$.

We determined the total monomeric anthocyanin content of urmu, black and white mulberries as 1072, 839 and $91 \mathrm{mg} / 100 \mathrm{~g}$ dry weight. [5] found anthocyanin in black mulberries $1221 \mathrm{mg} / 100 \mathrm{~g}$ dry weight (expressed as cyaniding -3-glucoside). The difference between the results may be attributed to fruit type and maturation period. Anthocyanin content of fruit is reported to change during ripening period. Over ripened, 
F. Hepsağ et al. / Hacettepe J. Biol. \& Chem., 2016, 44 (3), 225-231 | 229
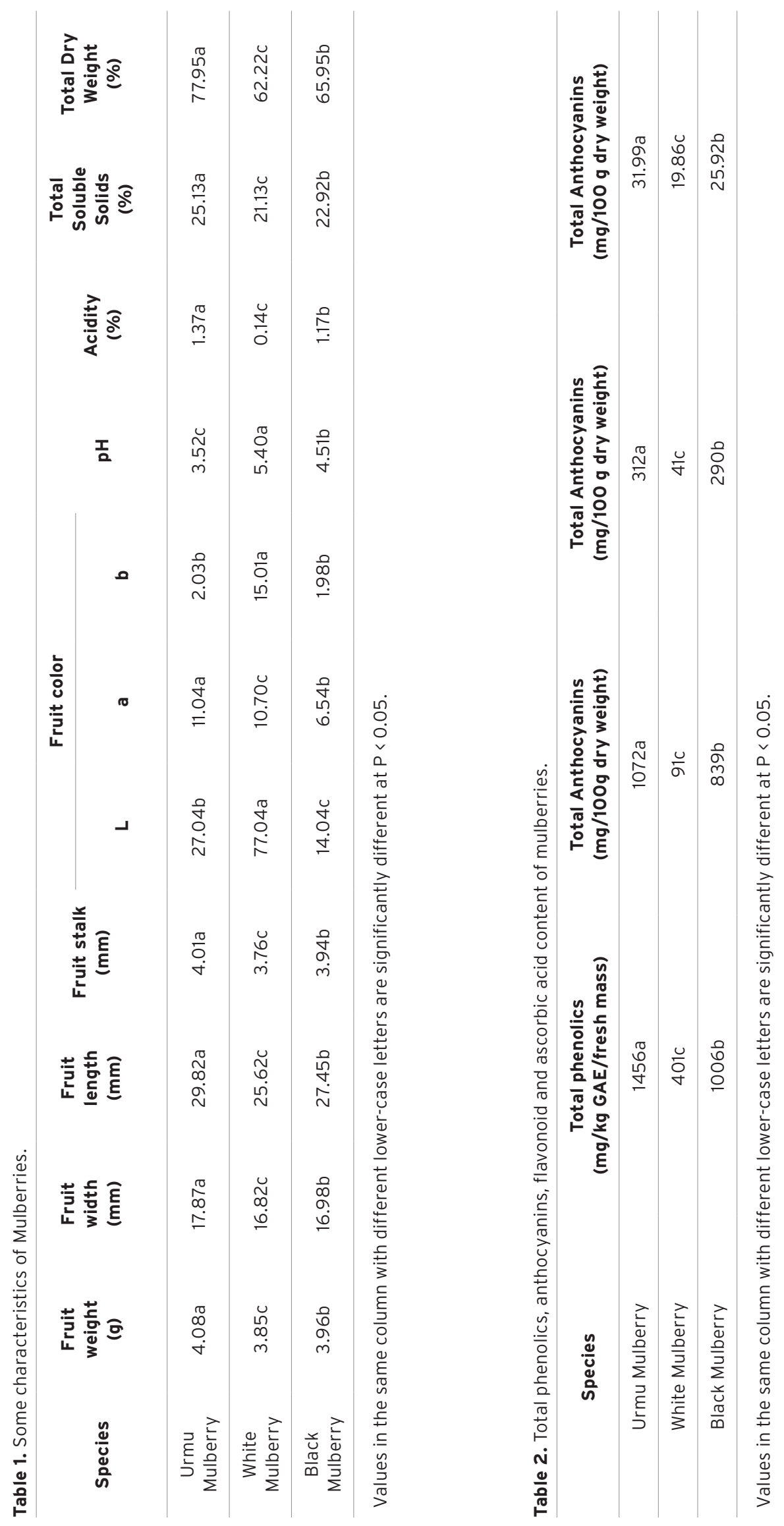
Table 3. HMF, Browning index and total fat content of mulberries.

\begin{tabular}{cccc}
\hline Species & $\begin{array}{c}\text { HMF } \\
(\mathbf{m g} / \mathbf{k g})\end{array}$ & Browning Index & $\begin{array}{c}\text { Total fat content } \\
\text { (\%) }\end{array}$ \\
\hline Urmu Mulberry & $6.77 \mathrm{c}$ & $6.63 \mathrm{~b}$ & $0.74 \mathrm{c}$ \\
\hline White Mulberry & $36.15 \mathrm{a}$ & $17.61 \mathrm{a}$ & $0.99 \mathrm{a}$ \\
\hline Black Mulberry & $13.29 \mathrm{~b}$ & $4.53 \mathrm{c}$ & $0.87 \mathrm{~b}$ \\
\hline
\end{tabular}

Values in the same column with different lower-case letters are significantly different at $P<0.05$.

Table 4. Mineral contents of mulberries.

\begin{tabular}{cccccccccc}
\hline & \multicolumn{8}{c}{ Mineral elements (mg/100 g) } \\
S & $\mathbf{P}$ & $\mathbf{K}$ & $\mathbf{C a}$ & $\mathbf{M g}$ & $\mathbf{N a}$ & $\mathbf{F e}$ & $\mathbf{C u}$ & $\mathbf{M n}$ & $\mathbf{Z n}$ \\
\hline $\begin{array}{c}\text { Urmu } \\
\text { Mulberry }\end{array}$ & $269 \mathrm{a}$ & $1205 \mathrm{a}$ & $156 \mathrm{a}$ & $131 \mathrm{a}$ & $71 \mathrm{a}$ & $7.7 \mathrm{a}$ & $1.2 \mathrm{a}$ & $6.5 \mathrm{a}$ & $4.8 \mathrm{a}$ \\
\hline $\begin{array}{c}\text { White } \\
\text { Mulbery }\end{array}$ & $211 \mathrm{c}$ & $1055 \mathrm{~b}$ & $121 \mathrm{c}$ & $104 \mathrm{c}$ & $58 \mathrm{c}$ & $4.0 \mathrm{c}$ & $0.4 \mathrm{c}$ & $2.5 \mathrm{c}$ & $2.7 \mathrm{c}$ \\
\hline $\begin{array}{c}\text { Black } \\
\text { Mulbery }\end{array}$ & $236 \mathrm{~b}$ & $1155 \mathrm{a}$ & $140 \mathrm{~b}$ & $115 \mathrm{~b}$ & $65 \mathrm{~b}$ & $5.5 \mathrm{~b}$ & $0.8 \mathrm{~b}$ & $4.0 \mathrm{~b}$ & $4.1 \mathrm{~b}$ \\
\hline
\end{tabular}

Values in the same column with different letters are significantly different at $P<0.05$.

purple-colored mulberry fruits contain the highest amount of anthocyanin, followed by purple-red and red-colored fruits. Purple colored mulberry fruits contain anthocyanin more than five times as compared to the red-colored ones [2].

Ascorbic acid contents of urmu, black and white mulberries were found as 31.99, 25.92 and $19.86 \mathrm{mg} / 100 \mathrm{~g}$, respectively. [2] found increased ascorbic acid in deep colored mulberry fruits, 1.4 $\mathrm{mg} / 100 \mathrm{~g}$ in purple, $2 \mathrm{mg} / 100 \mathrm{~g}$ in purple-red and $2.4 \mathrm{mg} / 100 \mathrm{~g}$ in red fruits.

\section{HMF, Browning Index and Total Fat Content of Mulberries}

HMF, Browning index and total fat content of mulberry types are given in Table 3. HMF contents of urmu, black and white mulberries were found as $6.77,13.29$ and $36.15 \mathrm{mg} / \mathrm{kg}$, respectively. [16] found HMF contents of fresh black mulberry juice between 45.40-46 mg/kg. They also explained that HMF content of both black mulberry juice and concentrate increased significantly $(p<0.01)$ with higher storage temperature and time.

Browning index of urmu, black and white mulberries were 6.63, 4.53 and 17.61, respectively. Higher antioxidant content of darker fruits may have prevented these fruits against browning reactions.

Fruits are known to contain very low amount of fat except oil fruits like olive, walnut and avacado etc. The total fat contents of the mulberries were found as $0.74 \%$ in urmu, $0.87 \%$ in black and $0.99 \%$ in white. [1] found similar values as $0.85 \%$ in M. rubra and $1.10 \%$ in M. alba. They also stated that there was a negative correlation between moisture and fat content of mulbery.

\section{Mineral Contents of Mulberries}

The mean amount of minerals in $100 \mathrm{~g}$ mulberry fruits were $238 \mathrm{mg} \mathrm{P}, 1138 \mathrm{mg} \mathrm{K}, 139 \mathrm{mg} \mathrm{Ca}, 116$ $\mathrm{mg} \mathrm{Mg}, 65 \mathrm{mg} \mathrm{Na}, 6 \mathrm{mg} \mathrm{Fe}, 0.8 \mathrm{mg} \mathrm{Cu}, 4.3 \mathrm{mg}$ $\mathrm{Mn}$ and $3.9 \mathrm{mg} \mathrm{Zn}$ (Table 4). [1] reported similar result in various mulberry types.

As seen in Table 4, urmu mulberries had highest values for all the minerals investigated, but white mulberries had lowest values. $K$ was the prodominant, and $\mathrm{Zn}$ was the least mineral in the present study. The mineral composition of fruits depends on the type or variety and the growing conditions, such as soil and geographical conditions. 


\section{CONCLUSIONS}

In the light of present study, increased levels of phenolic compounds, flavonoids, anthocyanin and ascorbic acid were found in deep - colored black and reddish black types. They also showed lower level of HMF and browning index propably due to higher levels of these antioxidant compounds. Of the mulberry types investigated, urmu (M. nigra L.) which has larger fruit width, length and weight, and atractive appearance, and rich in nutritional value, it is more convenient to consume as fresh and may be processed into diverse products including jam, and be used as ingredient in food processing such as confectionary. The possibility of use of urmu as food coloring should be investigated in further studies.

\section{ACKNOWLEDGEMENTS}

This project was supported by the University of Harran Committee of Scientific Research (HUBAK). Project Number; 1135, Researchers are thanks to Directorate of Harran University.

\section{References}

1. S. Ercisli, E. Orhan, Chemical composition of white (Morus alba L.), red (Morus rubra L.) and black (Morus nigra L.) mulberry fruits, Food Chem., 103 (2007) 1380-1384.

2. P. Aramwit, N. Bang, T. Srichana, The properties and stability of anthocyanins in mulberry fruits, Food Research International., 20 (2010) 1093-1097.

3. F. Hepsag, I. Hayoglu, B. Hepsag, Anthocyanin content of black mulberry fruit and its usage opportunities as color material in food industry, Electronic Journal of Food Technologies, 7 (2012) 9-19.

4. S. Kara, E.A. Erçelebi, Thermal degradation kinetics of anthocyanins and visual colour of urmu mulberry (Morus nigra L.), Journal of Food Engineering., 116 (2013) 541-547.
5. S. Kamiloglu, O. Serali, N. Unal, E. Capanoglu, Antioxidant activity and polyphenol composition of black mulberry (Morus nigra L.) Products, Journal of Berry Research, 3 (2013) 41-51.

6. B. Cemeroğlu, Gıda analizleri. Íkinci baskı. Gıda teknolojisi derneği yayınları no: 34, Ankara, composition of black mulberry (Morus nigra L.) products, Journal of Berry Research., 3 (2010) 41-51.

7. K. McLaren, Food Colorimetry, In: Walford J. Developments in Food Colours-I. London: Applied Science Publishers Ltd. (1980) 27-45.

8. M.M. Giusti, R.E. Wrolstad, Characterization of red radish anthocyanins, Journal of Food Sciences, 61 (1986) 322-326.

9. M. Caglarırmak, Ochratoxin A, Hydroxymethylfurfural and vitamin $\mathrm{C}$ levels of sun-dried grapes and sultanas, Journal of Food Processing and Preservation, 30 (2006) 549-562.

10. M.M.M. El Far, H.A.A. Taie, Antioxidant activities, total anthrocynins, phenolics and flavonoids contents of some sweet potato genotypes under stress of different concentrations of sucrose and sorbitol, Australian J. Basic Applied. Sc., 3 (2009) 3609-3616.

11. G.A. Spanos, R.E. Wrolstad, Phenolics of apple, pear, and white grape juice and their changes with processing and storage-a review, J. Agric. Food Chem., 40 (1992) 1478-1487.

12. AOAC, Association of Official Analytical Chemistry. Official methods of analytical chemist, (5th Ed.). Washington, DC. 1990.

13. NMKL, Nordic Committee on Food Analysis, Metals Determination By Atomic Absorbtion Spectrophotometry After Wet Digestion in a Microwave Oven. Nordic Committee on Food Analysis, No: 161 (1998) 1-8.SAS Institute, SAS/STAT.SAS Inst, Cary, NC, USA 2000.

14. D.S. Dimitrijevic, D.A. Kostic, G.S. Stojanovic, S.S. Mitic, M.N. Mitic, A.S. Dordevic, Phenolic composition, antioxidant activity, mineral content and antimicrobial activity of fresh fruit extracts of Morus alba $L$, Journal of Food and Nutrition Research, 53 (2005) 22-30.

15. T. Boranbayeva, F. Karadeniz, E. Yılmaz, Effect of storage on anthocyanin degradation in black mulberry juice and concentrates, Food Bioprocess Technol., 7 (2012) 1894-1902.

16. TFC, Turkish Food Codex. Feed Analysis, Offical Journal No. 25571, Ankara, 2004. 
